\title{
Covariation of sea ice and methanesulphonic acid in Wilhelm II Land, East Antarctica
}

\author{
Annette F.M. FOSTER, ${ }^{1}$ Mark A.J. CURRAN, ${ }^{2}$ Barbara T. SMITH, ${ }^{2}$ Tas D. VAN OMMEN, ${ }^{2}$ \\ Vin I. MORGAN ${ }^{2}$ \\ ${ }^{1}$ Institute of Antarctic and Southern Ocean Studies, University of Tasmania, Private Bag 77, Hobart, Tasmania 7001, Australia \\ ${ }^{2}$ Australian Government Antarctic Division and Antarctic and Climate Ecosystems CRC, Private Bag 80, Hobart, \\ Tasmania 7001, Australia \\ E-mail: mark.curran@utas.edu.au
}

\begin{abstract}
Sea ice plays an important role in ocean-atmosphere heat exchange, global albedo and the marine ecosystem. Knowledge of variation in sea-ice extent is essential in order to understand past climates, and to model possible future climate scenarios. This paper presents results from a short firn core spanning 15 years collected from near Mount Brown, Wilhelm II Land, East Antarctica. Variations of methanesulphonic acid (MSA) at Mount Brown were positively correlated with sea-ice extent from the coastal region surrounding Mount Brown $\left(60-120^{\circ} \mathrm{E}\right)$ and from around the entire Antarctic coast $\left(0-360^{\circ} \mathrm{E}\right)$. Previous results from Law Dome identified this MSA-sea-ice relationship and proposed it as an Antarctic sea-ice proxy (Curran and others, 2003), with the strongest results found for the local Law Dome region. Our data provide supporting evidence for the Law Dome proxy (at another site in East Antarctica), but a deeper Mount Brown ice core is required to confirm the sea-ice decline suggested by Curran and others (2003). Results also indicate that this deeper record may also provide a more circumAntarctic sea-ice proxy.
\end{abstract}

\section{INTRODUCTION}

Research utilizing Antarctic ice cores aims to investigate climate connections between the Southern Ocean and the atmosphere. Antarctic sea ice plays an essential role in regulation of the global climate, ocean circulation and biological productivity. In order to understand the link between sea ice and climate, an understanding of the variations in sea-ice extent is required (Nicol and Allison, 1997; Wu and others, 1999). Antarctic sea-ice extent has been found to respond to interannual climate variability arising from the El Niño-Southern Oscillation (ENSO) phenomenon (Meyerson and others, 2002), and sea ice is expected to be a sensitive indicator of climate change, declining in extent in response to higher atmospheric and oceanic temperatures (Jacka and Budd, 1998; Wolff and others, 2003). However, some models suggest that, with global warming, sea-ice extent is increasing due to the stabilizing effects of increased snowfall on the Southern Ocean (Zwally and others, 2002; Parkinson, 2004). Longer records are needed to fully understand the driving mechanisms behind sea-ice extent variability.

Satellite records of sea-ice extent span only the past few decades, so detecting a long-term trend from within the interannual variability of the sea-ice record is problematic. Identification of a proxy record of sea-ice extent would allow investigation of variability prior to satellite observation, thereby offering insights into long-term trends in sea-ice extent in East Antarctica. Evidence from ice-core chemistry records suggests that there is a link between methanesulphonic acid (MSA) production rates and sea-ice extent (Welch and others, 1993; Curran and others, 2003). MSA forms from oxidation of dimethylsulphide (DMS) produced by phytoplankton in the surface ocean water, with productivity directly influenced by sea ice and climatic factors such as ENSO (Curran and others, 1998b; Meyerson and others, 2002). Analysis of the MSA from a Law Dome ice core identified a significant correlation between the concentration of MSA and the extent of sea ice around the entire continent, with a stronger correlation for the local region of $80-140^{\circ} \mathrm{E}$ (Curran and others, 2003). This suggests that the Law Dome MSA record can be used as a sea-ice proxy for this region (Curran and others, 2003). The Law Dome MSA-sea-ice proxy indicates that there has been a decline in regional seaice extent since the 1950s (Curran and others, 2003), which is in agreement with other climate proxy studies that have also reported a decline in Antarctic sea ice (de la Mare, 1997; Wu and others, 1999; Barbraud and Weimerskirch, 2001; Wilson and others, 2001). The MSA-sea-ice proxy identified by Curran and others (2003) was derived from a single ice-core record. Data from other ice-core sites throughout Antarctica are required to confirm the validity of the MSA-sea-ice proxy and allow further investigation of sea-ice variability around Antarctica, and the longer-term trends in sea-ice extent.

This paper focuses on the record of MSA extracted from a short firn core collected from Wilhelm II Land, East Antarctica, and explores links between local sea-ice extent and MSA concentration, with comparison to the Law Dome MSA-sea-ice proxy proposed by Curran and others (2003).

\section{SAMPLING AND ANALYSIS}

A $10 \mathrm{~m}$ firn core was drilled using a hand auger near Mount Brown $\left(69.131^{\circ} \mathrm{S}, 85.997^{\circ} \mathrm{E} ; 2078 \mathrm{~m}\right.$ a.s.l.) as part of a larger survey in Wilhelm II Land (Fig. 1) (Smith and Ruddell, 2001; Smith and others, 2002). Wilhelm II Land is located inland of the West Ice Shelf, on the main East Antarctic ice sheet sloping towards the northwest/north-northwest, and is dominated by winds which sweep from the southeast across this sector of East Antarctica, as well as locally generated katabatic winds (King and Turner, 1997).

After collection, the Mount Brown firn core was sectioned into approximately $1 \mathrm{~m}$ lengths and sealed in plastic (Smith 


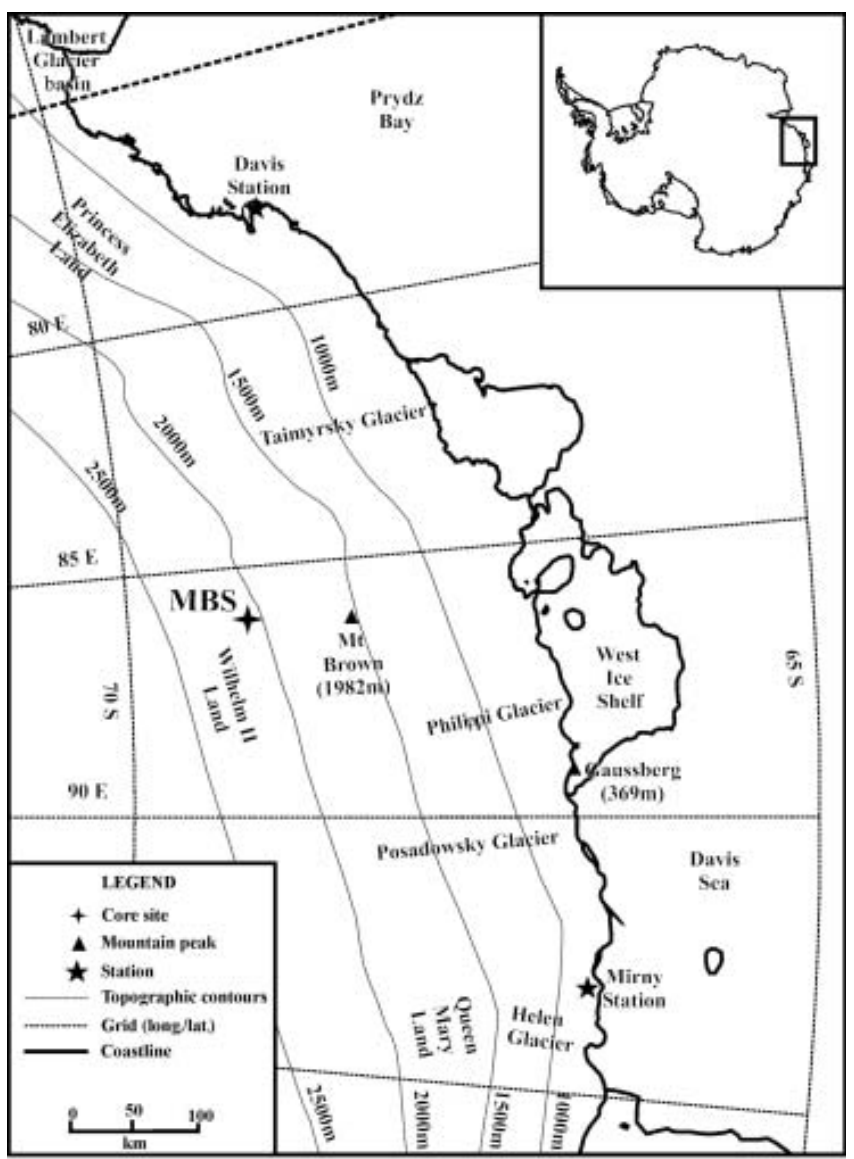

Fig. 1. Location of the Mount Brown firn core (MBS) in Wilhelm II Land (after Smith and Ruddell, 2001).

and Ruddell, 2001). All cores were then stored in plastic core trays within insulated PVC bags and stored at $-18^{\circ} \mathrm{C}$ in a blast freezer aboard the R/V Aurora Australis (Smith and Ruddell, 2001) until return to Australian Government Antarctic Division laboratories in Hobart.

The Mount Brown firn core was initially measured for a range of parameters including electrical conductivity, hydrogen peroxide $\left(\mathrm{H}_{2} \mathrm{O}_{2}\right)$ and oxygen isotope ratio $\left(\delta^{18} \mathrm{O}\right)$ relative to Vienna Standard Mean Ocean Water (VSMOW) (Smith and others, 2002). The core was then further sampled for a suite of trace ions (including MSA) in 2003 using the established sampling techniques and suppressed ion chromatography methods of Curran and Palmer (2001). Typical precision on the MSA measurements is $4 \%$.

Mount Brown is located sufficiently close to the coast to receive adequate accumulation to record seasonal variations in trace chemistry. A detailed stratigraphy of the firn core was undertaken prior to sampling, with no visible signs of melt present (Smith and Ruddell, 2001).

\section{DATING THE FIRN CORE}

The Mount Brown chemical record contained seasonal cycles, which were used to date the firn core. Seasonal cycles in trace chemicals have been successfully used to date ice cores elsewhere in Antarctica (e.g. Legrand and Delmas, 1985; Whitlow and others, 1992; MosleyThompson and others, 1993; Minikin and others, 1994; Curran and others, 1998a). A multi-species approach using the $\mathrm{H}_{2} \mathrm{O}_{2}$ record as the primary marker was undertaken (see

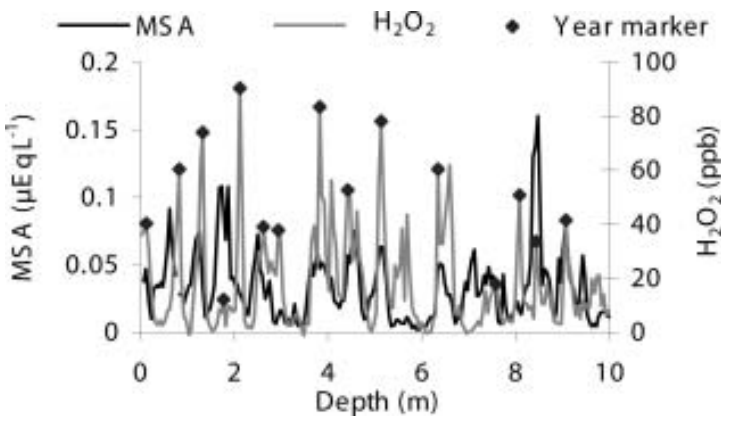

Fig. 2. Mount Brown MSA and $\mathrm{H}_{2} \mathrm{O}_{2}$ records, with year markers indicated by grey triangles.

Morgan and van Ommen, 1997), with year beginnings defined to coincide with the summer maxima in the $\mathrm{H}_{2} \mathrm{O}_{2}$ record (assumed to be at the summer solstice) (Fig. 2). Smith and Ruddell (2001) used the $\delta^{18} \mathrm{O}, \mathrm{H}_{2} \mathrm{O}_{2}$ and electrical conductivity records to date the Mount Brown core. The addition of trace chemical records in 2003 revised the initial dating scheme and determined that the Mount Brown core spanned 15 years, from 1984 to 1999. The trace chemical record was particularly useful in resolving sections of the firn core where the summer marker $\left(\mathrm{H}_{2} \mathrm{O}_{2}\right)$ became unclear. For example, MSA was also used as a summer marker (Fig. 2). Support for this new dating scheme was provided by an increase in the sulphate signal during 1992-94 from the volcanic eruption of Pinatubo, Philippines, (in 1991) and cross-matching of chemical signals (including the Pinatubo eruption) in a nearby core that spanned 7 years (1992-98). While there may be some uncertainty with the dating process below the Pinatubo eruption, it is unlikely to be more than \pm 1 year, and does not affect the findings presented in this paper.

\section{COMPARISON WITH SEA-ICE RECORDS}

It is well documented for Antarctica that with increasing distance inland and elevation, there is a decreased dominance of marine air masses and an increase in stratospheric source strength, which is reflected in the trace chemical record preserved in the ice (e.g. Bromwich, 1988; Mulvaney and Wolff, 1994; Legrand and Mayewski, 1997; Kreutz and Mayewski, 1999). This is also known to have a direct effect on the local accumulation rate (Bromwich, 1988). The Mount Brown firn core site (MBS) is located at $2078 \mathrm{~m}$ a.s.l. (Fig. 1) and approximately $200 \mathrm{~km}$ inland of the West Ice Shelf (Smith and Ruddell, 2001) and is estimated here to receive $297 \mathrm{~kg} \mathrm{~m}^{-2} \mathrm{a}^{-1}$. In contrast, Law Dome projects out from the coast of East Antarctica, with the summit of the dome at $1370 \mathrm{ma.s.l.,}$ and receives approximately $640 \mathrm{~kg} \mathrm{~m}^{-2} \mathrm{a}^{-1}$ (Morgan and others, 1997; Curran and others, 1998a). Accumulation rates of $>200 \mathrm{~kg} \mathrm{~m}^{-2} \mathrm{a}^{-1}$ are considered to be sufficient to preserve seasonal cycles in trace chemicals (Legrand and Mayewski, 1997).

MSA is reported to exhibit post-depositional movement, which may involve chemical reactions within the snowpack or a loss of MSA from the snowpack (Pasteur and Mulvaney, 2000; Curran and others, 2002; Delmas and others, 2003). The movement of MSA is believed to be related to the accumulation rate and the concentration of other trace chemicals within the snowpack (Pasteur and Mulvaney, 2000). This is most common in ice cores collected from 


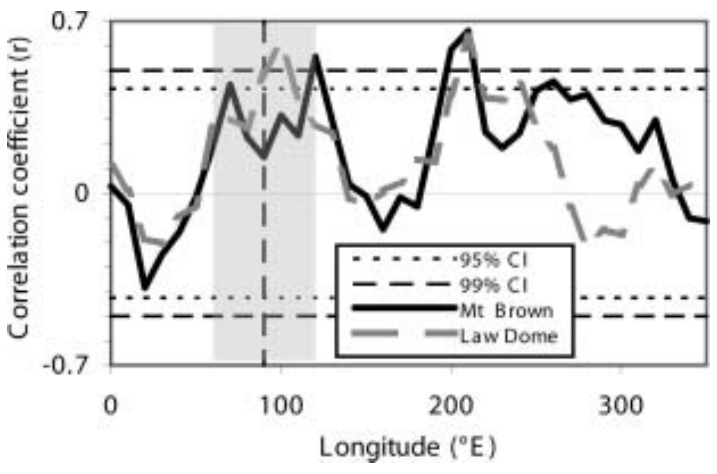

Fig. 3. Correlation coefficient between MSA at Mount Brown and Law Dome vs sea-ice extent at each longitude around Antarctica, between 1998 and 1994, where the vertical dotted line indicates the longitude of Mount Brown, and the shaded rectangle the local region $\left(60-120^{\circ} \mathrm{E}\right)$.

regions with low accumulation rates. On examination of the seasonal record of MSA, there was no evidence of postdepositional movement of MSA in the Mount Brown record.

The seasonal record of MSA from Mount Brown was compared to sea-ice extent records using the same method as Curran and others (2003). Austral summer-centred mean annual MSA concentrations were calculated for the 15 year ice-core record from Mount Brown (1984-98). The 15 year sea-ice extent record was obtained from mean monthly passive microwave data compiled by T.H. Jacka (data available on the Antarctic Climate and Ecosystems Cooperative Research Centre climate datasets website, http:// staff.acecrc.org.au/ jacka/climate). Using the same method as detailed in Curran and others (2003), the sea-ice extent for each year was calculated from the mean ice-edge latitude (15\% ice concentration) of August, September and October for each year. The MSA record from Mount Brown was compared with the sea-ice extent averaged from around the entire continent and then with each $10^{\circ}$ sector of longitude (Fig. 3). We acknowledge that this comparison is limited due to the short ice-core record from Mount Brown, but we find significant results with this comparison. While sea ice in the sector $\left(80^{\circ} \mathrm{E}\right)$ containing Mount Brown is not correlated with MSA, the wider $60-120^{\circ}$ E surrounding sector is significantly correlated $(r=0.51, p<0.05$, $n=15$; Fig. 4a). This suggests that the MSA signal is affected by atmospheric transport and mixing processes across a wider source region $\left(60-120^{\circ} \mathrm{E}\right)$ before reaching Mount Brown. However, due to the short length of this record (15 years), we are unable to identify specific MSA source regions to Mount Brown. In addition, the strongest correlation was found between Mount Brown and mean annual maximum sea-ice extent around the whole continent $(r=0.70, p<0.005, n=15$; Fig. 4b). This is not significantly stronger than the $60-120^{\circ} \mathrm{E}$ sector $(r=0.51)$, mainly due to the small number of years $(n=15)$, but suggests that a longer core from Mount Brown may provide a sea-ice proxy that better represents the circum-Antarctic sea-ice signal.

The sector $200-220^{\circ} \mathrm{E}$, which occurs in the Ross Sea, is also found to be significantly correlated with MSA concentrations at Mount Brown ( $r=0.53, p<0.05, n=15$; Fig. 3). The Law Dome MSA record was also correlated with seaice variations in the Ross Sea region (Curran and others,

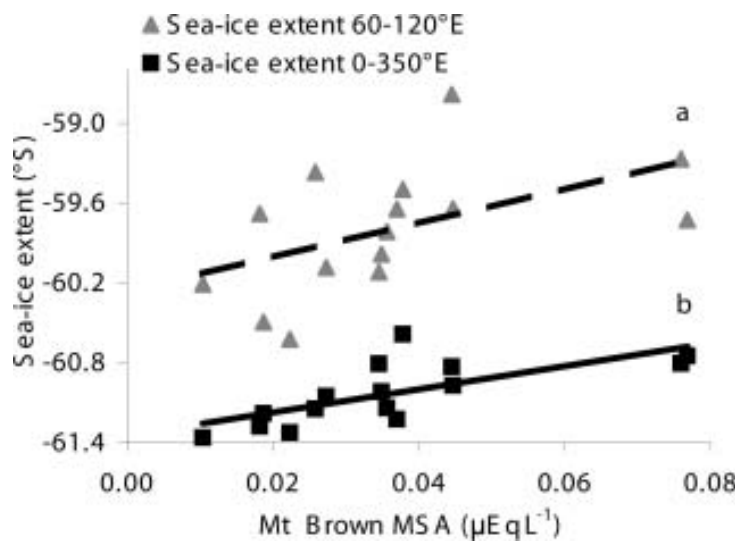

Fig. 4. Correlation between austral summer-centred mean annual MSA concentrations from Mount Brown (1984-98) and the local region (60-120 $\mathrm{E} ; 1985-97)$ (a) and sea-ice extent from around the whole continent $\left(0-360^{\circ} \mathrm{E} ; 1985-97\right)$ (b).

2003), and was most likely due to autocorrelations within the sea-ice distribution, rather than transport of MSA from the Ross Sea region to Law Dome.

The Law Dome MSA record has been proposed as a seaice extent proxy, with the MSA record suggesting a decline in Antarctic sea-ice extent since the 1950s (Curran and others, 2003). Comparisons between the preserved MSA record from Law Dome and Mount Brown suggest that a longer record taken from Mount Brown could help to confirm the trends seen in the Law Dome MSA record (Fig. 5). This could help to confirm the Law Dome MSA record as a proxy for sea-ice extent over time-spans not covered by instrumental data.

\section{CONCLUSIONS}

Research on the preserved trace chemical record of MSA from Law Dome by Curran and others (2003) has identified a relationship between the concentration of MSA and sea-ice extent. However, this proxy is currently only applicable to MSA records from Law Dome. We have identified another

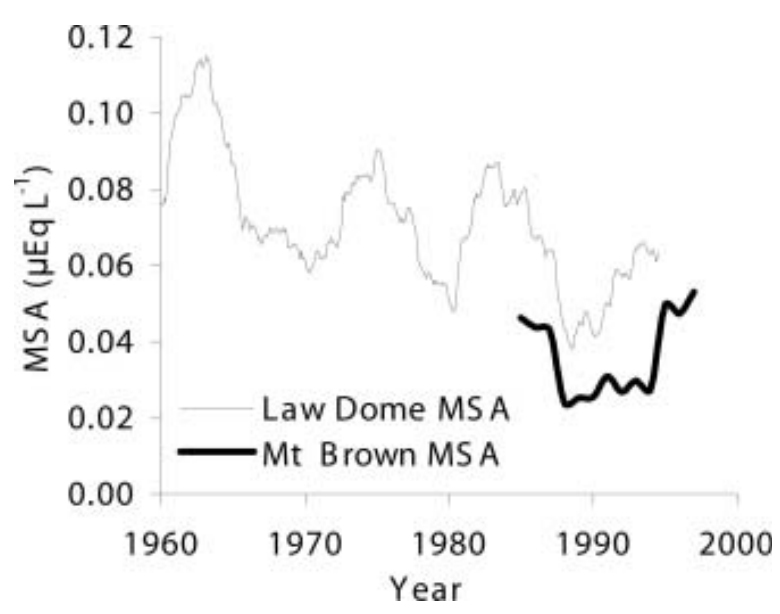

Fig. 5. Comparison of the Law Dome MSA record (1960-95; 3 year running mean) and the Mount Brown MSA record (1984-98; 3 year running mean). Note that the curves are offset due to differences in mean MSA concentration, which are due to differences in the source and transport of MSA. 
site, near Mount Brown, located in Wilhelm II Land on the main East Antarctic ice sheet, where the MSA-sea-ice proxy also appears to be valid, thus supporting the Law Dome MSA-sea-ice proxy. Further research using a longer core from this site or nearby in Wilhelm II Land would improve the validation of the Law Dome MSA-sea-ice proxy, and further assess the decline in sea-ice extent reported by Curran and others (2003). Investigations of MSA proxies from more sites around Antarctica are required before largescale generalizations about variations in sea-ice extent around Antarctica may be stated. The use of an MSAsea-ice proxy, at least in some coastal areas, may assist in understanding the link between marine biological activity, sea-ice extent and past climate change events, and therefore assist in modelling of future climate conditions.

\section{ACKNOWLEDGEMENT}

This work was supported by the Australian Government's Cooperative Research Centres Programme through the Antarctic Climate and Ecosystems Cooperative Research Centre (ACE CRC).

\section{REFERENCES}

Barbraud, C. and H. Weimerskirch. 2001. Emperor penguins and climate change. Nature, 411(6834), 183-186.

Bromwich, D.H. 1988. Snowfall in high southern latitudes. Rev. Geophys., 26(1), 149-168.

Curran, M.A.J. and A.S. Palmer. 2001. Suppressed ion chromatography methods for the routine determination of ultra low level anions and cations in ice cores. J. Chromatogr., Ser. A, 919(1), 107-113.

Curran, M.A.J., T.D. van Ommen and V. Morgan. 1998a. Seasonal characteristics of the major ions in the high-accumulation Dome Summit South ice core, Law Dome, Antarctica. Ann. Glaciol., 27, 385-390.

Curran, M.A.J., G.B. Jones and H. Burton. 1998b. The spatial distribution of DMS and DMSP in the Australasian sector of the Southern Ocean. J. Geophys. Res., 103(D13), 16,677-16,689.

Curran, M.A.J. and 6 others. 2002. Post-depositional movement of methanesulphonic acid at Law Dome, Antarctica, and the influence of accumulation rate. Ann. Glaciol., 35, 333-339.

Curran, M.A.J., T.D. van Ommen, V.I. Morgan, K.L. Phillips and A.S. Palmer. 2003. Ice core evidence for Antarctic sea ice decline since the 1950s. Science, 302(5648), 1203-1206.

De la Mare, W.K. 1997. Abrupt mid-twentieth century decline in Antarctic sea-ice extent from whaling records. Nature, 389(6646), 57-61.

Delmas, R.J., P. Wagnon, K. Goto-Azuma, K. Kamiyama and O. Watanabe. 2003. Evidence for the loss of snow-deposited MSA to the interstitial gaseous phase in central Antarctic firn. Tellus, 55B(1), 71-79.

Jacka, T.H. and W.F. Budd. 1998. Detection of temperature and seaice-extent changes in the Antarctic and Southern Ocean, 194996. Ann. Glaciol., 27, 553-559.

King, J.C. and J. Turner. 1997. Antarctic meteorology and climatology. Cambridge, etc., Cambridge University Press.
Kreutz, K.J. and P.A. Mayewski. 1999. Spatial variability of Antarctic surface snow glaciochemistry: implications for paleoatmospheric circulation reconstructions. Antarct. Sci., 11(1), 105-118.

Legrand, M. and R.J. Delmas. 1985. Spatial and temporal variations of snow chemistry in Terre Adélie (East Antarctica). Ann. Glaciol., 7, 20-25.

Legrand, M. and P. Mayewski. 1997. Glaciochemistry of polar ice cores: a review. Rev. Geophys., 35(3), 219-243.

Meyerson, E.A., P.A. Mayewski, K.J. Kreutz, L.D. Meeker, S.I. Whitlow and M.S. Twickler. 2002. The polar expression of ENSO and sea-ice variability as recorded in a South Pole ice core. Ann. Glaciol., 35, 430-436.

Minikin, A., D. Wagenbach, W. Graf and J. Kipfstuhl. 1994. Spatial and seasonal variations of the snow chemistry at the central Filchner-Ronne Ice Shelf, Antarctica. Ann. Glaciol., 20, 283-290.

Morgan, V. and T.D. van Ommen. 1997. Seasonality in lateHolocene climate from ice-core records. Holocene, 7(3), $351-354$

Morgan, V.I., C.W. Wookey, J. Li, T.D. van Ommen, W. Skinner and M.F. Fitzpatrick. 1997. Site information and initial results from deep ice drilling on Law Dome, Antarctica. J. Glaciol., 43(143), 3-10.

Mosley-Thompson, E., L.G. Thompson, J. Dai, M. Davis and P.N. Lin. 1993. Climate of the last 500 years: high resolution ice core records. Quat. Sci. Rev., 12(6), 419-430.

Mulvaney, R. and E.W. Wolff. 1994. Spatial variability of the major chemistry of the Antarctic ice sheet. Ann. Glaciol., 20, 440-447.

Nicol, S. and I. Allison. 1997. The frozen skin of the Southern Ocean. Am. Sci., 85(5), 426-439.

Parkinson, C.L. 2004. Southern Ocean sea ice and its wider linkages: insights revealed from models and observations. Antarct. Sci., 16(4), 387-400.

Pasteur, E.C. and R. Mulvaney. 2000. Migration of methane sulphonate in Antarctic firn and ice. J. Geophys. Res., 105(D9), 11,525-11,534.

Smith, B.T. and A. Ruddell. 2001. Snow accumulation in Wilhelm II Land, East Antarctica. Antarct. CRC Res. Rep. 22.

Smith, B.T., T.D. van Ommen and V.I. Morgan. 2002. Distribution of oxygen isotope ratios and snow accumulation rates in Wilhelm II Land, East Antarctica. Ann. Glaciol., 35, 107-110.

Welch, K.A., P.A. Mayewski and S.I. Whitlow. 1993. Methanesulfonic acid in coastal Antarctic snow related to sea ice extent. Geophys. Res. Lett., 20(6), 443-446.

Whitlow, S., P.A. Mayewski and J.E. Dibb. 1992. A comparison of major chemical species seasonal concentration and accumulation at the South Pole and Summit, Greenland. Atmos. Environ., 26A(11), 2045-2054.

Wilson, P.R. and 6 others. 2001. Adélie penguin population change in the Pacific sector of Antarctica: relation to sea-ice extent and the Antarctic circumpolar current. Mar. Ecol. Progr. Ser. 213, 301-309.

Wolff, E.W., A.M. Rankin and R. Röthlisberger. 2003. An ice core indicator of Antarctic sea ice production? Geophys. Res. Lett., 30(22), 2158. (10.1029/2003GL018454.)

Wu, X., W.F. Budd and T.H. Jacka. 1999. Simulations of Southern Hemisphere warming and Antarctic sea-ice changes using global climate models. Ann. Glaciol., 29, 61-65.

Zwally, H.J., J.C. Comiso, C.L. Parkinson, D.J. Cavalieri and P. Gloersen. 2002. Variability of Antarctic sea ice 1979-1998. J. Geophys. Res., 107(C5), 3041. (10.1029/2000JC000733.) 